\title{
Nutrient Content and Uptake in Rice (Oryza sativa L.) under the Influence of Long Term Balance Fertilizer Application
}

\author{
Reshma Bora ${ }^{1 *}$, Aaradhana Chilwal ${ }^{2}$, P.C. Pandey ${ }^{3}$ and Reetika Bhaskar ${ }^{3}$ \\ ${ }^{1}$ Department of Agriculture, UCBMS\&H, Dehradun, Uttarakhand, India \\ ${ }^{2}$ Punjab Agricultural University, Ludhiana, Punjab, India \\ ${ }^{3}$ Department of Agronomy, GBPUA\&T, Pantnagar, Uttarakhand, India \\ *Corresponding author
}

\begin{tabular}{|l|}
\hline K e y w o r d s \\
HKR 47, Znf, FYMr, \\
$\begin{array}{l}\text { Long-term fertility } \\
\text { experiment, Nitrogen, } \\
\text { Phosphorus, Potassium }\end{array}$ \\
\hline Article Info \\
\hline $\begin{array}{l}\text { Accepted: } \\
\text { 12 August } 2018 \\
\text { Available Online: } \\
\text { 10 September } 2018\end{array}$
\end{tabular}

\section{A B S T R A C T}

The present study is a part of long-term fertility experiment carried out since 1984 and was conducted at A2 block of N. E. Borlaug Crop Research Centre of G.B. Pant University of Agriculture and Technology, Pantnagar (Uttarakhand) during kharif 2017. Nine treatments out of fourteen consisting different combination of N, P, K, Znf and FYM were tested in a Randomized Block Design with four replications. The variety sown was HKR 47. In this study nitrogen, phosphorus and potassium content in rice grain and straw; uptake of nitrogen, phosphorus and potassium by rice grain and straw; and total uptake was evaluated. Results revealed that different treatments had significant effect on nutrient content and uptake in rice. Treatment with recommended dose of fertilizer to rice, $\mathrm{N}_{120} \mathrm{P}_{40} \mathrm{~K}_{40}+\mathrm{Znf}$, gave higher values of all, nitrogen, phosphorus and potassium content and uptake, over other treatments with only inorganic fertilizer application. But FYM application along with NPK and NPK $+\mathrm{Zn}$ enhanced concentration of nutrients as well as their uptake and that increased significantly with the application of N, P, K Zn and FYM applied in balanced combination. The highest values of nitrogen, phosphorus and potassium content uptake in rice were obtained under $\mathrm{N}_{120} \mathrm{P}_{40} \mathrm{~K}_{40}+\mathrm{Znf}+\mathrm{FYMr}$ and $\mathrm{N}_{120} \mathrm{P}_{40} \mathrm{~K}_{40}+\mathrm{FYMr}$ treatments. Higher values of nutrient content and uptake directly relates to better productivity of crop, thus the higher values of nutrient content and uptake in FYM applied treatments in comparison to other treatments showed its importance indirectly in producing better yield by rice crop.

\section{Introduction}

Rice and wheat have been grown in sequence on the same land over 26.m.ha of South and East Asia to meet the food demand of increasing population. The study of soil fertility and crop productivity under long-term cropping has long been the subject of immense importance.
There are indications of declining productivity due to depletion in soil organic matter, over mining of nutrients reserves and losses of nutrients as clearly evolved through long-term fertilizer experiments being conducted in different parts of the country. Presently, the major concern in agriculture is to arrest any further decline in the crop productivity and soil quality. 
Sustainable high yields of crops can support food security of the rapidly growing population (Palm et al., 2014). Management of rice production is the keystone for sustainability and productivity of rice-wheat cropping system as rice (Oryza sativa L.) is a staple food for billions of people around the world. About $90 \%$ of the world's rice is grown and consumed in Asia, where $50 \%$ of the world's population resides. Rice consumption is increasing and demand for rice will outstrip supply if production does not increase faster than its current rate. This means there is a need to produce even more rice for food security. Improved fertility status of soil health and could support sustainable crop production. Long-term fertility experiments have significantly contributed to our understanding of soil fertility management and sustainable crop production in different agro ecosystems (Rawal et al., 2017).

In developing countries, fertilizer is used by the inadequate amount and an imbalanced way. The general recommendation of NPK fertilizers resulted in soil fatigue, proving their diseased efficiency and thus requires upward refinement and a proper balance among the macro and micronutrient (Yadav and Kumar, 2009). Under intensive cropping system, high use of fertilizer can cause a deficiency of primary, secondary and micronutrients. Presently farmer is using only NPK, that too in imbalance ratio and there is no attention paid for secondary and micronutrients. Longterm fertility experiments, however, are a good indicator for monitoring soil quality and crop productivity and are of vital importance in nutrient management as well as soil health also (Paul et al., 2013).

Balanced fertilization significantly effects nutrient content and uptake by any crop which further affects the yield of the crop. The crop yields of rice in the $36^{\text {th }}$ year of experimentation revealed that highest production of $5.4 \mathrm{t} \mathrm{ha}^{-1}$ of rice grain was obtained by combined application of FYM and $100 \%$ NPK. The beneficial effect of FYM might be due to its favorable effect on the availability of macro and micronutrients and better uptake of nutrients by rice grain and straw as compared to $100 \%$ NPK alone (Agarwal, 2008). From the result of LTFEs established at Ludhiana in 1993, Kumar et al., (2008) found that the application of FYM along with $100 \%$ NPK produced significantly higher grain yield $\left(6.71 \mathrm{q} \mathrm{ha}^{-1}\right)$ of rice than $100 \%$ NPK (5.87 q ha ${ }^{-1}$ of rice) alone which may be due to better content of nitrogen, phosphorus and potassium in grain. Behera and Singh (2009) concluded the results obtained from field trial conducted at IARI, New Delhi, the highest grain and straw yields of wheat were obtained under $100 \%$ NPK + Zn which were statistically at par with $100 \%$ NPK + FYM but were found significantly higher as compared to other treatments. In the same experiment total uptake of nitrogen was found better in FYM applied treatments. Integrated use of chemical fertilizers and FYM maintained the highest productivity of about $30-35 \mathrm{q} \mathrm{ha}^{-1}$ as against 22-27 $\mathrm{q} \mathrm{ha}^{-1}$ with NPK alone. The FYM addition, thus, realized about $8 \mathrm{q} \mathrm{ha}^{-1}$ higher yields over NPK alone (Sharma et al., 1998) because of better effect of nutrient content of crop. Yaduvanshi (2003) reported that application of NPK and its combination with green manure and FYM increased the rice yield significantly. Applying inorganic fertilizers resulted in similar NUE in rice as that with organic manures along with inorganic fertilizers but in wheat, the residual effect of organic manures along with inorganic fertilizers increased the NUE than NPK alone. A field study conducted during 1997-98 to 1998-99, Niranjan and Singh (2005) reported that the application of organic manures with inorganic fertilizers significantly increased the grain yield of rice. The yield of rice grain increased significantly with level of fertilizer up to $100 \%$ NPK than $50 \%$ NPK, $50 \%$ NP and 
$50 \% \mathrm{~N}$. The continuous cropping of ricewheat resulted in yield decline over years. This happened as the incomplete fertilizer application was not able to fulfill the uptake requirements of crop. Highest grain yield was obtained with application of $\mathrm{N}_{180} \mathrm{P}_{40} \mathrm{~K}_{40}+$ $\mathrm{Znf}+\mathrm{FYM}$ in rice-wheat at Pantnagar which was statistically higher than other treatments except for $\mathrm{N}_{120} \mathrm{P}_{40} \mathrm{~K}_{40}+\mathrm{FYM}, \mathrm{N}_{180} \mathrm{P}_{60} \mathrm{~K}_{40}+$ Znf + FYM and $\mathrm{N}_{180} \mathrm{P}_{60} \mathrm{~K}_{40}+\mathrm{Znf}$ (Paul et $a l ., 2013)$. This was ascribed to the continuous and balanced supply of $\mathrm{N}, \mathrm{P}, \mathrm{K}$ and $\mathrm{Zn}$ along with FYM that led to better nutrient content in rice. Many experiments reported the importance of better nutrient content and uptake in giving higher yield level and so this experimented was conducted with the objective to determine the influence of long term fertilizer application on nutrient content and uptake by rice crop.

\section{Material and methods}

In Kharif, 1984, the long-term fertility experiment on rice-wheat cropping system was initiated under the flagship of International Network on Soil Fertility and Fertilizer Evaluation for Rice (INSFER) programme of Indian Council of Agricultural Research (ICAR) and International Rice Research Institute (IRRI) and the same ricewheat cropping system with same sets of treatments is practiced on the same piece of experimental site.

Field experiment was conducted in kharif season 2017 at A2 Block of Norman E. Borlaug Crop Research Center (NEBCRC) of G.B.P.U.A\&T. Pantnagar, Udham Singh Nagar, (Uttarakhand). This center is situated at an altitude of $243.84 \mathrm{~m}$ above mean sea level, $29^{\circ} \mathrm{N}$ Latitude and $79.3^{\circ} \mathrm{E}$ longitude. It falls under foot hills of Shivalik range of Himalayas as a narrow belt called "Tarai". The Tarai belt falls under the sub-humid and sub-tropical climate zone with hot dry summers and cool winters. The soils are originated from alluvial sediments. The chemical analysis of top $15 \mathrm{~cm}$ soil showed that it was rich in organic matter and medium in phosphorus and potassium, and neutral to slightly alkaline in reaction. In the long term fertility experiment, fourteen treatments were tested in a Randomized Block Design 4 replications, however only nine important treatments (Control, $\mathrm{N}_{120}, \mathrm{~N}_{120} \mathrm{P}_{40}, \mathrm{P}_{40} \mathrm{~K}_{40}$, $\mathrm{N}_{120} \mathrm{~K}_{40}, \quad \mathrm{~N}_{120} \mathrm{P}_{60} \mathrm{~K}_{40}, \quad \mathrm{~N}_{120} \mathrm{P}_{40} \mathrm{~K}_{40}+\mathrm{Znf}$, $\mathrm{N}_{120} \mathrm{P}_{40} \mathrm{~K}_{40}+\mathrm{FYMr}$ and $\mathrm{N}_{120} \mathrm{P}_{40} \mathrm{~K}_{40}+\mathrm{Znf}+$ FYMr) considered in the present study. The above mentioned symbols represent : $\mathrm{N}_{120}-120$ $\mathrm{kg} \mathrm{N} \mathrm{ha}{ }^{-1}, \mathrm{P}_{40}-40 \mathrm{~kg} \mathrm{P}_{2} \mathrm{O}_{5} \mathrm{ha}^{-1}, \mathrm{~K}_{40}-40 \mathrm{~kg} \mathrm{~K}_{2} \mathrm{O}$ ha $^{-1}$, Znf- Foliar Zinc $\left(0.5 \% \mathrm{ZnSO}_{4}+0.25 \%\right.$ Slaked lime), FYMr- Farm Yard Manure applied@5 tha ${ }^{-1}$ on the dry weight basis in rice crop only.

\section{Results and Discussion}

\section{Nitrogen content and uptake in plant}

The data pertaining to nitrogen content and its uptake by grain and straw are summarized in Table 1. Addition of FYM to a recommended dose of fertilizer led to significant increase in nitrogen content and uptake compared to recommended dose of fertilizer. The highest nitrogen content in grain was recorded due to $\mathrm{N}_{120} \mathrm{P}_{40} \mathrm{~K}_{40}+\mathrm{Znf}+\mathrm{FYMr}(1.50 \%)$ which was statistically at par with $\mathrm{N}_{120} \mathrm{P}_{40} \mathrm{~K}_{40}+\mathrm{FYMr}$ (1.49\%) and $\mathrm{N}_{120} \mathrm{P}_{40} \mathrm{~K}_{40}$ (1.47\%). Comparing with a recommended dose of fertilizer $\mathrm{N}_{120} \mathrm{P}_{40} \mathrm{~K}_{40}+\mathrm{Znf}$, it is noticed that nitrogen content in grain due to $\mathrm{N}_{120} \mathrm{P}_{40} \mathrm{~K}_{40}+\mathrm{Znf}$ was at par with $\mathrm{N}_{120} \mathrm{P}_{40} \mathrm{~K}_{40}, \mathrm{~N}_{120} \mathrm{~K}_{40}$ and $\mathrm{N}_{120} \mathrm{P}_{40}$ but significantly more than control and $\mathrm{P}_{40} \mathrm{~K}_{40}$. The highest nitrogen content in straw was observed with $\mathrm{N}_{120} \mathrm{P}_{40} \mathrm{~K}{ }_{40}+$ FYMr $(0.50 \%)$ which was at par with $\mathrm{N}_{120} \mathrm{P}_{40} \mathrm{~K}_{40}+\mathrm{Znf}(0.47$ $\%)$ significantly more than all other treatments. All the fertilizer treatments increased nitrogen uptake by grain significantly over control except $\mathrm{P}_{40} \mathrm{~K}_{40}$. The 
highest uptake was recorded in $\mathrm{N}_{120} \mathrm{P}_{40} \mathrm{~K}_{40}+\mathrm{Znf}+\mathrm{FYMr}\left(91.24 \mathrm{~kg} \mathrm{ha}^{-1}\right)$ which was at par with $\mathrm{N}_{120} \mathrm{P}_{40} \mathrm{~K}+\mathrm{FYMr}_{40}(90.50 \mathrm{~kg}$ $\mathrm{ha}^{-1}$ ) but significantly higher than all other fertilizer treatments. Comparison with a recommended dose of fertilizer indicated that nitrogen uptake due to a recommended dose of fertilizer $\mathrm{N}_{120} \mathrm{P}_{40} \mathrm{~K}_{40}+$ Znf was at par with $\mathrm{N}_{120} \mathrm{P}_{40} \mathrm{~K}_{40}$ but significantly less than $\mathrm{N}_{120} \mathrm{P}_{40} \mathrm{~K}_{40}+\mathrm{Znf}+\mathrm{FYMr}$ and significantly more than other treatments. The maximum nitrogen uptake by straw was recorded with $\mathrm{N}_{120} \mathrm{P}_{40} \mathrm{~K}_{40}+$ FYMr $\left(31.21 \mathrm{~kg} \mathrm{ha}^{-1}\right)$ which was at par with $\mathrm{N}_{120} \mathrm{P}_{40} \mathrm{~K}_{40}+\mathrm{Znf}+\mathrm{FYMr}$ but significantly higher than all other treatments. All the fertilizer treatments except $\mathrm{P}_{40} \mathrm{~K}_{40}$ had significantly higher nitrogen uptake than control.

The highest total nitrogen uptake was due to $\mathrm{N}_{120} \mathrm{P}_{40} \mathrm{~K}_{40}+$ FYMr (121.71 $\left.\mathrm{kg} \mathrm{ha}^{-1}\right)$ which was at par with $\mathrm{N}_{120} \mathrm{P}_{40} \mathrm{~K}_{40}+\mathrm{Znf}+\mathrm{FYMr}$ $\left(120.41 \mathrm{~kg} \mathrm{ha}^{-1}\right)$ but recorded significantly higher values than all other treatments. The lowest total nitrogen uptake was recorded with control (43.99 kg ha-1). The same trend as that of nitrogen uptake by grain was observed with respect to a comparison of the recommended dose of fertilizer.

\section{Phosphorus content and uptake in plant}

The data pertaining to phosphorus content and its uptake by grain and straw are summarized in Table 2. Addition of FYM to a recommended dose of fertilizer led to significant increase in phosphorus content and uptake compared to recommended dose of fertilizer. The maximum content of phosphorus in grain was recorded due $\mathrm{N}_{120} \mathrm{P}_{40} \mathrm{~K}_{40}+\mathrm{Znf}+\mathrm{FYMr}(0.388 \%)$ which was at par with $\mathrm{N}_{120} \mathrm{P}_{40} \mathrm{~K}_{40}+\mathrm{Znf}(0.383 \%)$, $\mathrm{N}_{120} \mathrm{P}_{40} \mathrm{~K}_{40} \quad(0.376 \%) \quad \mathrm{P}_{40} \mathrm{~K}_{40} \quad(0.377 \%)$ and $\mathrm{N}_{120} \mathrm{P}_{40}(0.371 \%)$ and all these treatments resulted in significantly higher phosphorus content in grain than other treatments. Comparing with a recommended dose of fertilizer $\mathrm{N}_{120} \mathrm{P}_{40} \mathrm{~K}_{40}+\mathrm{Znf}$ indicated that phosphorus content due to $\mathrm{N}_{120} \mathrm{P}_{40} \mathrm{~K}_{40}+\mathrm{Znf}$ was at par with $\mathrm{N}_{120} \mathrm{P}_{40} \mathrm{~K}_{40}, \quad \mathrm{~N}_{120} \mathrm{P}_{40}$, $\mathrm{N}_{120} \mathrm{P}_{40} \mathrm{~K}_{40}+\mathrm{FYMr}$ and $\mathrm{N}_{120} \mathrm{P}_{40} \mathrm{~K}_{40}+\mathrm{Znf}+$ FYMr but significantly more than other treatments. The highest content of phosphorus in straw was recorded in $\mathrm{N}_{120} \mathrm{P}_{40} \mathrm{~K}+\mathrm{Znf}+$ FYMr $(0.167 \%)$ which was significantly higher than all other treatments. All the fertilizer treatments significantly increased the phosphorus uptake by grain over control. The highest phosphorus uptake by grain was found with $\mathrm{N}_{120} \mathrm{P}_{40} \mathrm{~K}_{40}+\mathrm{Znf}+\mathrm{FYMr}\left(23.05 \mathrm{~kg} \mathrm{ha}^{-1}\right)$ followed by $\mathrm{N}_{120} \mathrm{P}_{40} \mathrm{~K}_{40}+\mathrm{FYMr}(22.27 \mathrm{~kg}$ $\mathrm{ha}^{-1}$ ) and $\mathrm{N}_{120} \mathrm{P}_{40} \mathrm{~K}_{40}+\mathrm{Znf}\left(21.65 \mathrm{~kg} \mathrm{ha}^{-1}\right)$ these were at par with each other but significantly higher phosphorus uptake by grain than other treatments. The highest phosphorus uptake by straw was recorded with $\mathrm{N}_{120} \mathrm{P}_{40} \mathrm{~K}_{40}+$ FYMr (10.55 $\mathrm{kg} \mathrm{ha}^{-1}$ ) followed by $\mathrm{N}_{120} \mathrm{P}_{40} \mathrm{~K}_{40}+\mathrm{Znf}+$ FYMr $\left(10.30 \mathrm{~kg} \mathrm{ha}^{-1}\right)$ both were at par with each other but significantly higher than all the fertilizer treatments. All the treatment caused significantly higher total phosphorus uptake over control except $\mathrm{N}_{120}$ and $\mathrm{N}_{120} \mathrm{~K}$. The highest total phosphorus uptake was recorded with $\mathrm{N}_{120} \mathrm{P}_{40} \mathrm{~K}_{40}+\mathrm{Znf}+\mathrm{FYMr}\left(33.35 \mathrm{~kg} \mathrm{ha}^{-1}\right.$ ) followed by $\mathrm{N}_{120} \mathrm{P}_{40} \mathrm{~K}_{40}+\mathrm{FYMr}\left(32.83 \mathrm{~kg} \mathrm{ha}^{-1}\right)$ which was at par with each other but significantly higher than all other fertilizer treatments.

\section{Potassium content and uptake in plant}

The data pertaining to potassium content and its uptake by grain and straw are summarized in Table 3. Similar to nitrogen and phosphorus, addition of FYM led to significant increase in phosphorus content and uptake compared to recommended dose of fertilizer. The highest content of potassium in grains was recorded in $\mathrm{N}_{120} \mathrm{P}_{40} \mathrm{~K}_{40}+\mathrm{Znf}+$ FYMr $(0.450 \%)$ which was significantly higher potassium content than all other treatments. 
Table.1 Effect of treatments on nitrogen content and uptake by rice

\begin{tabular}{|c|c|c|c|c|c|}
\hline \multirow[t]{2}{*}{ Treatment } & \multicolumn{2}{|c|}{ Content (\%) } & \multicolumn{3}{|c|}{ Uptake $\left(\mathrm{kg} \mathrm{ha}^{-1}\right)$} \\
\hline & Grain & Straw & Grain & Straw & Total \\
\hline Control & 1.18 & 0.30 & 34.45 & 9.54 & 43.99 \\
\hline $\mathbf{N}_{120}$ & 1.40 & 0.41 & 48.75 & 15.60 & 64.35 \\
\hline $\mathbf{N}_{120} P_{40}$ & 1.41 & 0.44 & 71.76 & 24.65 & 96.41 \\
\hline $\mathbf{P}_{40} \mathbf{K}_{40}$ & 1.11 & 0.32 & 39.17 & 12.51 & 51.68 \\
\hline $\mathbf{N}_{120} \mathbf{K}_{40}$ & 1.42 & 0.43 & 53.75 & 17.64 & 71.39 \\
\hline $\mathbf{N}_{120} \mathbf{P}_{40} \mathbf{K}_{40}$ & 1.47 & 0.45 & 75.00 & 24.41 & 99.40 \\
\hline $\mathbf{N}_{120} \mathbf{P}_{40} K_{40}+\mathrm{Znf}$ & 1.44 & 0.47 & 81.40 & 28.52 & 109.92 \\
\hline $\mathbf{N}_{120} \mathbf{P}_{40} \mathbf{K}_{40}+\mathrm{FYMr}$ & 1.49 & 0.50 & 90.50 & 31.21 & 121.71 \\
\hline $\mathrm{N}_{120} \mathbf{P}_{40} \mathrm{~K}_{40}+\mathrm{Znf}+\mathrm{FYMr}$ & 1.50 & 0.45 & 91.24 & 29.17 & 120.41 \\
\hline S.Em \pm & 0.013 & 0.013 & 2.27 & 0.83 & 2.80 \\
\hline C.D. $(5 \%)$ & 0.04 & 0.04 & 6.54 & 2.4 & 8.23 \\
\hline C.V. $(\%)$ & 1.92 & 6.02 & 6.84 & 7.7 & 6.48 \\
\hline
\end{tabular}

Table.2 Effect of balanced fertilizer on Phosphorus content and uptake by rice

\begin{tabular}{|l|}
\hline Treatment \\
\hline Control \\
\hline $\mathbf{N}_{120}$ \\
\hline $\mathbf{N}_{120} \mathbf{P}_{40}$ \\
\hline $\mathbf{P}_{40} \mathbf{K}_{40}$ \\
\hline $\mathbf{N}_{120} \mathbf{K}_{40}$ \\
\hline $\mathbf{N}_{120} \mathbf{P}_{40} \mathbf{K}_{40}$ \\
\hline $\mathbf{N}_{120} \mathbf{P}_{40} \mathbf{K}_{40}+\mathbf{Z n f}$ \\
\hline $\mathbf{N}_{120} \mathbf{P}_{40} \mathbf{K}_{40}+\mathbf{F Y M r}$ \\
\hline $\mathbf{N}_{120} \mathbf{P}_{40} \mathbf{K}_{40}+\mathrm{Znf}+\mathbf{F Y M r}$ \\
\hline S.Em \pm \\
\hline C.D. $(5 \%)$ \\
\hline C.V. $(\%)$ \\
\hline
\end{tabular}

\begin{tabular}{|l|l|l|l|l|}
\hline Content (\%) & & \multicolumn{3}{|l|}{ Uptake $\left(\mathbf{k g ~ h a}^{-\mathbf{1}}\right)$} \\
\hline Grain & Straw & Grain & Straw & Total \\
\hline 0.264 & 0.121 & 7.74 & 3.88 & 11.62 \\
\hline 0.273 & 0.103 & 9.52 & 3.98 & 13.50 \\
\hline 0.371 & 0.121 & 18.85 & 6.71 & 25.56 \\
\hline 0.377 & 0.127 & 13.68 & 4.93 & 18.61 \\
\hline 0.268 & 0.104 & 10.17 & 4.21 & 14.39 \\
\hline 0.376 & 0.146 & 19.20 & 7.89 & 27.09 \\
\hline 0.383 & 0.132 & 21.65 & 8.08 & 29.73 \\
\hline 0.368 & 0.158 & 22.27 & 10.30 & 32.83 \\
\hline 0.388 & 0.167 & 23.05 & 10.55 & 33.35 \\
\hline 0.006 & 0.002 & 0.60 & 0.20 & 0.71 \\
\hline 0.020 & 0.007 & 1.7 & 0.57 & 2.1 \\
\hline 3.80 & 3.7 & 7.4 & 5.8 & 6.2 \\
\hline
\end{tabular}

Table.3 Effect of treatments on potassium content and uptake by rice

\begin{tabular}{|l|l|l|l|l|l|l|}
\hline \multirow{2}{*}{ Treatment } & & \multicolumn{3}{|l|}{ Content $(\%)$} & \multicolumn{3}{l|}{ Uptake $\left(\mathbf{k g ~ h}^{-\mathbf{1}}\right)$} \\
\hline $\mathbf{T}_{\mathbf{1}}$ & Control & Grain & Straw & Grain & Straw & Total \\
\hline $\mathbf{T}_{\mathbf{2}}$ & $\mathrm{N}_{120}$ & 0.362 & 1.323 & 10.61 & 42.38 & 52.99 \\
\hline $\mathbf{T}_{\mathbf{3}}$ & $\mathrm{N}_{120} \mathrm{P}_{40}$ & 0.376 & 1.294 & 13.11 & 49.95 & 63.06 \\
\hline $\mathbf{T}_{\mathbf{4}}$ & $\mathrm{P}_{40} \mathrm{~K}_{40}$ & 0.361 & 1.238 & 18.41 & 69.01 & 87.42 \\
\hline $\mathbf{T}_{\mathbf{5}}$ & $\mathrm{N}_{120} \mathrm{~K}_{40}$ & 0.381 & 1.298 & 13.45 & 50.66 & 64.11 \\
\hline $\mathbf{T}_{\mathbf{6}}$ & $\mathrm{N}_{120} \mathrm{P}_{40} \mathrm{~K}_{40}$ & 0.407 & 1.311 & 15.35 & 53.55 & 68.90 \\
\hline $\mathbf{T}_{\mathbf{7}}$ & $\mathrm{N}_{120} \mathrm{P}_{40} \mathrm{~K}_{40}+\mathrm{Znf}$ & 0.397 & 1.303 & 20.29 & 70.63 & 90.92 \\
\hline $\mathbf{T}_{\mathbf{8}}$ & $\mathrm{N}_{120} \mathrm{P}_{40} \mathrm{~K}_{40}+\mathrm{FYMr}$ & 0.406 & 1.303 & 24.10 & 79.87 & 103.96 \\
\hline $\mathbf{T}_{\mathbf{9}}$ & $\mathrm{N}_{120} \mathrm{P}_{40} \mathrm{~K}_{40}+\mathrm{Znf}+\mathrm{FYMr}$ & 0.426 & 1.333 & 24.61 & 84.19 & 108.81 \\
\hline & S.Em \pm & 0.450 & 1.421 & 27.46 & 93.19 & 120.65 \\
\hline & C.D. $(5 \%)$ & 0.007 & 0.024 & 0.80 & 2.6 & 3.25 \\
\hline & C.V. $(\%)$ & 0.021 & 0.072 & 2.34 & 7.63 & 9.55 \\
\hline
\end{tabular}


Comparing with recommended fertility dose $\mathrm{N}_{120} \mathrm{P}_{40} \mathrm{~K}_{40}+\mathrm{Znf}(0.406 \%)$, it was noticed that potassium content due to a recommended dose of fertilizer was at par with $\mathrm{N}_{120} \mathrm{~K}_{40}$, $\mathrm{N}_{120} \mathrm{P}_{40} \mathrm{~K}_{40}+\mathrm{FYMr}$ and $\mathrm{N}_{120} \mathrm{P}_{40} \mathrm{~K}_{40}$ but significantly more than other inorganic treatments, hence enriching $\mathrm{N}_{120} \mathrm{P}_{40} \mathrm{~K}_{40}+$ FYMr and $\mathrm{N}_{120} \mathrm{P}_{40} \mathrm{~K}_{40}+\mathrm{Znf}+\mathrm{FYMr}$ led to significant increase in potassium content. In all the potassium deficient treatments the content of potassium was least. This indicates the necessity of adding potassium in soil with time to time.

The highest potassium content in straw was observed with $\mathrm{N}_{120} \mathrm{P}_{40} \mathrm{~K}+\mathrm{Znf}+\mathrm{FYMr}$ $(1.421 \%)$, which was significantly higher than all other fertilizer treatments. Comparing with the recommended dose of fertilizer $\mathrm{N}_{120} \mathrm{P}_{40} \mathrm{~K}$ $+\mathrm{Znf}(1.303 \%)$ indicated that all the inorganic treatments and control were at par with $\mathrm{N}_{120} \mathrm{P}_{40} \mathrm{~K}+\mathrm{FYMr}$ with respect to potassium content but enriching $\mathrm{N}_{120} \mathrm{P}_{40} \mathrm{~K}+$ FYMr or $\mathrm{N}_{120} \mathrm{P}_{40} \mathrm{~K}+\mathrm{Znf}(1.303 \%)$ with FYM caused significantly enhanced potassium content. The highest potassium uptake by grain was recorded with $\mathrm{N}_{120} \mathrm{P}_{40} \mathrm{~K}+\mathrm{Znf}$ + FYMr $\left(27.46 \quad \mathrm{~kg} \quad \mathrm{ha}^{-1}\right)$, which was significantly higher than all the fertilizer treatments. Comparing with $\mathrm{N}_{120} \mathrm{P}_{40} \mathrm{~K}+\mathrm{Znf}$ $\left(24.10 \mathrm{~kg} \mathrm{ha}^{-1}\right)$ indicated that potassium uptake due to $\mathrm{N}_{120} \mathrm{P}_{40} \mathrm{~K}+$ FYMr was at par but significantly less than $\mathrm{N}_{120} \mathrm{P}_{40} \mathrm{~K}+\mathrm{Znf}+$ FYMr and significantly more than other treatments.

All the fertilizer treatments except $\mathrm{N}_{120}, \mathrm{P}_{40} \mathrm{~K}$, and $\mathrm{N}_{120} \mathrm{~K}$ significantly increased the potassium uptake by straw over control. The highest potassium uptake by straw was recorded with $\mathrm{N}_{120} \mathrm{P}_{40} \mathrm{~K}+\mathrm{Znf}+\mathrm{FYMr}(93.19 \mathrm{~kg}$ $\mathrm{ha}^{-1}$ ), which was found significantly superior to all the fertilizer treatments. The trend with respect to comparison with $\mathrm{N}_{120} \mathrm{P}_{40} \mathrm{~K}+\mathrm{FYMr}$ was same as that in potassium uptake by grain. The highest total potassium uptake was recorded with $\mathrm{N}_{120} \mathrm{P}_{40} \mathrm{~K}_{40}+\mathrm{Znf}+\mathrm{FYMr}(120.65$ $\mathrm{kg} \mathrm{ha}^{-1}$ ), which was significantly higher than all the fertilizer treatments.

The study concluded that FYM application led to higher nitrogen, phosphorus and potassium content in rice grain and straw; uptake of nitrogen, phosphorus and potassium by rice grain and straw; and total uptake over recommended dose of fertilizer and other treatments. This shows the importance of FYM over recommended dose of fertilizer in improving the nutrient use efficiency of nitrogen, phosphorus and potassium, which would further lead to higher rice yield.

\section{References}

Agarwal, M. 2008. Monitoring soil physical, chemical and microbiological properties and nutrients uptake after 35 years of continuous fertilizer use in rice-wheat system. Ph. D. Thesis submitted to G.B.P.U.A. \& T., Pantnagar, India, 153 p.

Behera, S. K. and Singh, Dhyan 2009. Effect of 31 years of continuous cropping and fertilizer use on soil properties and uptake of micronutrients by maize (Zea mays)-wheat (Triticum aestivum) system. Indian J. Agri. Sci. 79(4): 264270.

Kumar, Balwinder, Gupta, R. K. and Bhandari, A. L. 2008. Soil fertility changes after long-term application of organic manures and crop residue under rice-wheat system. J. Indian Soc. Soil Sci. 56(1): 80-85.

Niranjan, R. K. and Bharat Singh. 2005. Effect of organic and inorganic fertilizers on yield and uptake of rice and their residual response on wheat crop. Farm Science Journal 14(2): 2324.

Palm, C Blanco., Canqui H., Clerck F., Gatere L and Grace P (2014) Conservation 
agriculture and ecosystem services: An overview. Agric Ecosyst Environ 187: $87-105$ DOI: 10.1016/j.agee.2013.10.010

Paul, T., Bisht, P.S., Pandey, P.C., Singh, D.K. and Roy, S. 2013. Rice productivity and soil fertility as influenced by nutrient management in rice (Oryza sativa)-wheat (Triticum aestivum) cropping system. Ind. $J$. Agro., 58(4): 495-499.

Rawal, N, Ghimire, R and Devraj Chalise. 2017. Crop Yield and Soil Fertility Status of Long-Term Rice-Rice-Wheat Cropping Systems. Indian Journal of applied science and biotechnology. $5(1): 42-50$

Sharma, S. P., Sharma, J. and Subehia, S. K. 1998. Integrated long-term effects of chemical fertilizers on crops yields, nutrients uptake and soil environment in western Himalayan soils. In: Swarup, A., Reddy, D.D., Prasad, R.N. (Eds.), Long-term soil fertility management through integrated plant nutrient supply. IISS, Bhopal, India, pp-125-138.

Yadav, D. S. and Kumar, Alok 2009. Longterm effect of nutrient management on soil health and productivity of rice (Oryza sativa)-wheat (Triticum aestivum) system. Indian J. Agron. 54(1): $15-23$

Yaduvanshi, N. P. S. 2003. Substantiation of inorganic fertilizers by organic manures and the effect on soil fertility in a ricewheat rotation on reclaimed sodic soil in India. Indian J. Agri.Sci. 140: 161-168.

\section{How to cite this article:}

Reshma Bora, Aaradhana Chilwal, P.C. Pandey and Reetika Bhaskar. 2018. Nutrient Content and Uptake in Rice (Oryza sativa L.) under the Influence of Long Term Balance Fertilizer Application. Int.J.Curr.Microbiol.App.Sci. 7(09): 2011-2017. doi: https://doi.org/10.20546/ijcmas.2018.709.243 